\title{
CLINICAL-EPIDEMIOLOGICAL STUDY OF LEPTOSPIROSIS IN HUMANS AND RESERVOIRS IN YUCATÁN, MÉXICO
}

\begin{abstract}
SUMMARY
A leptospirosis clinical-epidemiological study was made in humans and reservoirs in the state of Yucatán, México. Interviews and serological analyses were made on 400 persons from an open population, 439 probable cases of leptospirosis and 1060 animal reservoirs (cows, pigs, dogs, rats and opossums). IgM Leptospira Dipstick ${ }^{\mathrm{TM}}$ and Microscopic Agglutination Test (MAT) was used to detect human antibodies to leptospiras and serovar respectively. Leptospirosis incidence in humans was 2.2/100,000 inhab. in 1998, 0.7/100,000 in 1999 and 0.9/100,000 in 2000. Overall seroprevalence was 14.2\%, relatively unchanged from seroprevalences observed 20 years ago. Highest seropositivity was found in people over 56 years of age, predominating males over females. Predominant serovars in the open population were tarassovi, hardjo, pomona and panama. Leptospirosis cases were most frequent in rural areas, and the anicteric course predominated over the icteric. The panama, icterohaemorrhagiae and pomona serovars predominated in both anicteric and icteric courses. Dogs, pigs and rodents had the highest seropositivity among the reservoirs. Contact with rodents and natural water sources were significant factors $(\mathrm{p} \leq 0.05)$. Human cases $(74 \%)$ occurred during the rainy season. It is concluded that leptospirosis is still a serious illness with important clinical and epidemiological implications in the state of Yucatán, Mexico.
\end{abstract}

KEYWORDS: Leptospirosis; Prevalence; Incidence; Cases; México.

\section{INTRODUCTION}

Leptospirosis is a common zoonosis worldwide that affects mammals, including human beings. Infection is endemic and occurs with greatest frequency in tropical and subtropical regions. Both humans and animals can be directly infected through contact with infected tissue or urine, or indirectly through contact with contaminated soil and water ${ }^{5,6}$. Leptospirosis in humans occurs in two courses: anicteric or benign (between 85 and $90 \%$ of cases); and icteric or serious, also known as Weil's disease (between 10 and $15 \%$ of cases). The wide spectrum of clinical symptoms that characterize leptospirosis make its diagnosis to be easily confused with other febrile diseases ${ }^{11}$.

The first leptospirosis cases in México were reported in the State of Yucatán in 1920 by NOGUCHI \& KLIEGER, followed by the discovery of human cases in the State of Veracruz by BUSTAMANTE in 1937. Research continued in 1958 with the studies of VARELA et al. ${ }^{16}$ demonstrating leptospira antibodies in humans and animals from México City, and again in 1961 VARELA \& ZAVALA $^{18}$ studied 9,931 human and animal sera in Mexico. Isolated reports began to appear, mostly sero-epidemiological ${ }^{1,2,22}$. As in many other countries, the study of human leptospirosis in Mexico has been hampered by a lack of laboratories with diagnostic capabilities of this disease.
After the work of NOGUCHI during the $20^{\text {th }}$ no further studies were reported until 1962, when interest in the disease was renewed after VARELA \& ZAVALA $^{17}$ reported six positive leptospirosis cases in 56 icteric patients, mostly of the pomona serotype. A number of serious cases (Weil's disease) have been reported since 1977, with some of them being fatal ${ }^{21,23,25}$. In 1984, it was reported that $14 \%$ of the state's population was leptospirosis seropositive ${ }^{24}$. And in 1998, anicteric leptospirosis cases were found that had been erroneously diagnosed as dengue during an epidemic outbreak of this virosis ${ }^{26}$. However, this isolated information is insufficient to define the epidemiological behavior of this zoonosis in Yucatán

In response to this need, the present study is an integrated approach including analysis of seroprevalence, incidence, most common clinical course, circulating serovars and transmission factors for the 1998 to 2000 period.

\section{MATERIALS AND METHODS}

STUDY AREA: The state of Yucatán, México is located on the Yucatán Peninsula, between $19^{\circ} 40^{\prime}$ and $21^{\circ} 37^{\prime}$ North Latitude, and $87^{\circ} 30^{\prime}$ and $90^{\circ} 26^{\prime}$ 'West Latitude. Average daytime temperature is relatively high, generally above $30{ }^{\circ} \mathrm{C}$, with annual rainfall of $750 \mathrm{~mm}$ 


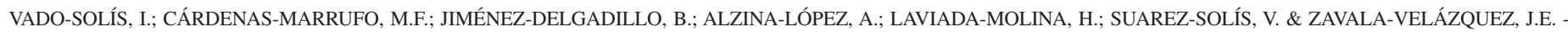
Clinical-epidemiological study of leptospirosis in humans and reservoirs in Yucatán, México. Rev. Inst. Med. trop. S. Paulo, 44(6):335-340, 2002.

and average relative humidity of $74 \%$. Geographically, the state is within the worldwide intertropical belt, and thus experiences microclimatic and meteorological phenomena typical of this zone, such as easterly trade winds, cold north winds, hurricanes, etc. There is no surface-running water (i.e. rivers, streams) in the state, though there are a number of rainfall deposits, locally known as "aguadas" or "cenotes". These have always been centers for human settlement. Vegetation in the area is semiarid and fauna is typical of these zones.

SEROPREVALENCE STUDY IN HUMANS: Seroprevalence in the state was determined using the EPI-INFO (version 6.04a) computer software program, with a total universe equal to the state's population of approximately $1,600,000$ people. Sample size was calculated using a $95 \%$ confidence level, a 5\% precision level and an estimated prevalence of 50\% (given that the last serological study in Yucatán was over 16 years ago). Resulting sample size was $\mathrm{N}=385$, which was increased to 400 for this study. The study design was submitted to and approved by the scientific and human ethics committee of the Faculty of Medicine, Universidad Autónoma de Yucatán.

To collect the necessary samples, 65 municipalities were randomly chosen from the 106 municipalities in the state. Within each municipality, people were included in the study that voluntarily participated by providing a blood sample and by being interviewed, and that met the inclusion criterion of not having had presumptive leptospirosis symptomatology at least two months before sampling. Intra-venous blood samples were obtained and coagulated by centrifuging at $1500 \mathrm{rpm}$ for 15 minutes. The resulting serum was stored in Eppendorf tubes at $-20{ }^{\circ} \mathrm{C}$ until use.

To determine seroprevalence and serovar, the microscopic agglutination test (MAT) was used, as described by TURNER ${ }^{13}$ and MYERS $^{10}$. Ten serovars were used as antigens based on previous studies in the region ${ }^{19,24,26}$ : canicola, pomona, wolffi, hardjo, tarassovi, panama, icterohaemorrhagiae, grippotyphosa, bratislava and pyrogenes. The cutoff point was dilutions $\geq 1$ : 100 and the predominant serovar was that with the highest dilution.

For the interviews, a questionnaire that included subject name and address, usual epidemiological data such as age, sex, location, contact with potential transmission factors such as domestic animals (dogs, bovines, and pigs), peridomestic animals (rodents, opossums), and contact with natural water sources (cenotes and aguadas), and stored water was given. A statistical association analysis was made of these variables for the $\chi^{2}$ test, with 0.05 significance levels (i.e. a value of $\mathrm{p} \leq 0.05$ suggests an association between two variables).

CLINICAL CASE STUDY: Subjects were those sent to the Faculty of Medicine by various clinics and hospitals in the state due to exhibition of presumptive leptospirosis symptoms. These subjects originated from 44 different locations in Yucatán, and had clinical histories. Antileptospira IgM Dipsticks ${ }^{\mathrm{TM}}$ Leptospira (Integrated Diagnostics Inc. Baltimore, MD, USA) were used to detect positive cases, and MAT was used to determine serovar.

Positive cases were analyzed using epidemiological data such as age, sex, regional distribution, and serovar, as well as clinical data like signs and symptoms. Annual incidence and monthly frequency were calculated, as was regional monthly rainfall. All data were recorded in the EPI-INFO (version 6.04a) computer software program, and descriptive statistical analyses was used to analyze the data.

Case definition: Considering the pleomorphism of the disease, confirmed cases of leptospirosis, were those in which the main symptom was fever plus three or more universally accepted clinical symtoms or signs of leptospirosis and positive IgM dipsticks.

RESERVOIR STUDY: A study was done to identify the presence of leptospira antibodies in animal reservoirs in different farms and ranches in the state. Blood samples were taken from 375 bovines and 353 pigs through piercing of the jugular vein, from 192 dogs through piercing of the cephalic vein, and from 60 rodents (Rattus rattus) and 80 opossum (Didelphis virginianus) through piercing of the heart after anesthesia with sodium pentobarbital (Pfizer). Serum was separated by centrifugation and stored at $-20{ }^{\circ} \mathrm{C}$ until use. The micro agglutination test was used to detect seropositives and serovar. Antigen and cut-off value were as those used for the human seroprevalence study.

\section{RESULTS}

HUMAN SEROPREVALENCE STUDY: Of the 400 human serum samples processed for MAT, 57 (14.2\%) seropositive samples were identified. Reactivity was generally high in the age groups, except in subjects younger than 15 years of age, with predominance in subjects older than 56 years of age, though without significant differences $(\mathrm{p} \geq$ 0.05 ) between groups. There was, however, a clear predominance of male subjects over females subjects, which was a statistically significant difference $(\mathrm{p} \leq 0.05)$ (Table 1$)$.

Table 1

Seroreactivity frequency, by age and sex, in Yucatán, México

\begin{tabular}{lccc}
\hline Sample size & 400 & $\begin{array}{c}\text { Positives } \\
57\end{array}$ & $\begin{array}{c}\% \\
14.2\end{array}$ \\
\hline Age groups * & & & \\
$<15$ & 25 & 1 & 4.0 \\
$15-35$ & 161 & 21 & 13.0 \\
$36-56$ & 160 & 25 & 15.6 \\
$>56$ & 54 & 10 & 18.5 \\
\hline Sex $* *$ & & & \\
Female & 266 & 31 & 11.6 \\
Male & 134 & 26 & 19.4 \\
\hline
\end{tabular}

$* \mathrm{p} \geq 0.05 ; * * \mathrm{p} \leq 0.05$

In serovar frequency, the tarassovi was predominant, though the hardjo, pomona and panama serovars also had relatively high percentages (Table 2).

The studied transmission factors were found to be widely distributed throughout the state. When a statistical association analysis was done, however, a significant association was only found between living with rodents $(\mathrm{p} \leq 0.05)$ and contact with natural water deposits (aguadas and cenotes) $(\mathrm{p} \leq 0.05)$ (Table 3$)$. 
Table 2

Positivity per serogroup and serovar in Yucatán, México

\begin{tabular}{lccc}
\hline Serogroup & Serovar & Positives & $\%$ \\
\hline Tarassovi & tarassovi & 10 & 17.5 \\
Sejroe & hardjo & 7 & 12.3 \\
Pomona & pomona & 7 & 12.3 \\
Panama & panama & 5 & 10.5 \\
Icterohaemorrhagiae & icterohaemorrhagiae & 5 & 8.8 \\
Grippotyphosa & grippotyphosa & 5 & 8.8 \\
Pyrogenes & pyrogenes & 4 & 7.0 \\
Canicola & canicola & 4 & 7.0 \\
Sejroe & Wolffi & 2 & 3.5 \\
Australis & bratislava & 1 & 1.7 \\
Not processed & Not processed & 6 & 10.5 \\
Total & & 57 & 100 \\
\hline
\end{tabular}

Table 3

Contact frequency with transmission factors in a population from Yucatán, México

\begin{tabular}{|c|c|c|c|c|c|c|}
\hline Contact with reservoirs & $\begin{array}{c}\text { People surveyed } \\
400\end{array}$ & $\%$ & $\begin{array}{c}\text { Negative } \\
343\end{array}$ & $\%$ & $\begin{array}{c}\text { Positive } \\
57\end{array}$ & $\%$ \\
\hline Rodents * & 262 & 65.5 & 219 & 63.8 & 44 & 77.2 \\
\hline Dogs & 286 & 71.5 & 247 & 72.0 & 39 & 68.4 \\
\hline Opossums & 240 & 60.0 & 206 & 60.0 & 33 & 58.0 \\
\hline Pigs & 120 & 30.0 & 102 & 29.7 & 17 & 29.8 \\
\hline Bovines & 53 & 13.2 & 43 & 12.5 & 10 & 17.5 \\
\hline Inadequate water storage & 267 & 66.7 & 230 & 67 & 37 & 65.0 \\
\hline $\begin{array}{l}\text { Contact with natural } \\
\text { water deposits } * *\end{array}$ & 93 & 23.2 & 74 & 21.6 & 19 & 33.3 \\
\hline
\end{tabular}

$* \mathrm{p} \leq 0.05 ; * \mathrm{p} \leq 0.05$

CASE STUDIES: 61 confirmed leptospirosis cases during the period 1998-2000 were identified in the study. A greater number of cases were present in rural areas (36 cases; 20.5\%) than in urban areas (25 cases; $9.5 \%)$, which was a significant difference ( $\mathrm{p} \leq 0.05)$. Women cases also predominated over those in men $(39 ; 16.5 \%$ vs. $22 ; 10.8 \%)$ in both rural and urban areas, though this was not a significant difference $(\mathrm{p} \geq 0.05)$.

The most affected of the age groups was that for subjects between the ages of 15 and 35 years, though this was not statistically significant $(\mathrm{p} \geq 0.05)$.

Of the total of 61 seropositive cases, $52(85.2 \%)$ contracted the anicteric or benign course and $9(14.8 \%)$ contracted the icteric or serious course, this being a significant difference (Table 4). Frequency of signs and symptoms in the anicteric cases included fever (100\%), cephalalgia $(90.4 \%)$, and myalgia (84.6\%), whereas in the icteric cases the most frequent were fever, cephalalgia, choluria and icterus (100\%) (Table 5).

Serovar determination via MAT was done for only 31 of the 52 anicteric cases because serum condition did not allow for use of this technique with the remaining 21 cases. In the 31 anicteric cases subjected to MAT, the panama serovar was predominant, accounting for 12 cases $(38.7 \%)$,
Table 4

Frequency in population by area, sex, age and clinical course for 61 leptospirosis cases from Yucatán, México (1998-2000)

\begin{tabular}{llccc}
\hline Serum & & Total & Positive & $\%$ \\
& & 439 & 61 & 13.9 \\
\hline Area * & urban & 263 & 25 & 9.5 \\
& rural & 176 & 36 & 20.5 \\
& female & 236 & 39 & 16.5 \\
Sex ** & male & 203 & 22 & 10.8 \\
& & & & \\
Age $* *$ & $15-35$ & 200 & 9 & 8.6 \\
& $36-55$ & 99 & 10 & 18 \\
& $>56$ & 35 & 6 & 17 \\
& anicteric & & 52 & 85.2 \\
Clinical & icteric & & & \\
Course * & & & 9 & 14.8 \\
\hline$* \mathrm{p} \leq 0.05 ; * \mathrm{p}$ & 0.05 & & &
\end{tabular}




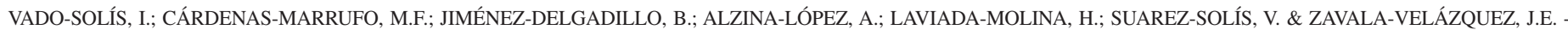
Clinical-epidemiological study of leptospirosis in humans and reservoirs in Yucatán, México. Rev. Inst. Med. trop. S. Paulo, 44(6):335-340, 2002.

Table 5

Frequency of signs and symptoms in leptospirosis patients from Yucatán, México (1998-2000)

\begin{tabular}{lcc}
\hline Anicteric & \# cases & $\%$ \\
Fever & 52 & 100 \\
Cephalalgia & 47 & 90.4 \\
Myalgia & 44 & 84.6 \\
Arthralgia & 41 & 78.8 \\
Ocular syndrome & 33 & 63.5 \\
Nasopharingeal symptoms & 27 & 51.7 \\
Gastrointestinal symptoms & 16 & 30.7 \\
Hepatomegaly and splenomegaly & 2 & 3.8 \\
Total cases & 52 & 100 \\
& & \\
Icteric & cases & \% \\
Fever, cephalalgia, icterus and choluria & 9 & 100 \\
Gastrointestinal symptoms & 8 & 88.8 \\
Ocular symptoms & 7 & 77.7 \\
Myalgia and arthralgia & 6 & 66.6 \\
Hepatomegaly and splenomegaly & 6 & 66.6 \\
Hyperazoemia & 5 & 55.5 \\
Total cases & 9 & 100 \\
\hline
\end{tabular}

followed by the pomona, accounting for 8 cases (25.8\%). In the 9 icteric cases, the icterohaemorrhagiae serovar predominated with 3 cases $(33.3 \%)$, followed by the panama with 2 cases (22.2\%) (Table 6).

The $72 \%$ of the cases occurred during the rainy season in the region (June to October), along all three years of the study.

Recorded incidence varied from year to year, being 2.2/100,000 inhab. in 1998, 0.7/100,000 inhab. in 1999, and 0.9/100,000 inhab. in 2000. None of the studied cases throughout the three-year period resulted in mortality.

\section{Table 6}

Seropositivity and microagglutination by serogroup and serovar in diseased patients from Yucatán, México (1998-2000)

\begin{tabular}{llcc}
\hline Serogroup & Serovar & \multicolumn{2}{c}{ Positive } \\
& & Anicteric & Icteric \\
\hline Panama & panama & $12(38.7 \%)$ & $2(22.2 \%)$ \\
Pomona & Pomona & $8(25.8 \%)$ & $1(11.1 \%)$ \\
Australis & bratislava & $3(9.7 \%)$ & 0 \\
Icterohaemorrhagiae & icterohaemorrhagiae & $2(6.5 \%)$ & $3(33.3 \%)$ \\
Grippotyphosa & grippotyphosa & $2(6.5 \%)$ & $1(11.1 \%)$ \\
Sejroe & Wolffi & $2(6.5 \%)$ & 0 \\
Sejroe & Hardjo & $1(3.2 \%)$ & $1(11.1 \%)$ \\
Tarassovi & tarassovi & $1(3.2 \%)$ & 0 \\
Canicola & canicola & 0 & $1(11.1 \%)$ \\
Pyrogenes & pyrogenes & 0 & 0 \\
Total & & $31(100 \%)$ & $9(100 \%)$ \\
\hline
\end{tabular}

21 Serum samples not processed.
RESERVOIR STUDIES: The three species found to have the highest seropositivity for leptospira antibodies were pigs 88 (25\%), dogs 36 $(19 \%)$ and rodents $9(15 \%)$, followed by bovines $21(5.6 \%)$, and opossums $4(5 \%)$. The predominant serotypes in pigs were the bratislava, icterohaemorrhagiae and panama; in bovines they were hardjo and tarassovi; in dogs they were grippotyphosa and pomona; in rodents they were icterohaemorrhagiae, wolffi and bratislava; and in opossums they were pomona and wolffi (Table 7).

Table 7

Seropositivity and serovar reservoirs from Yucatán, México

\begin{tabular}{lccc}
\hline Reservoirs & \# of animals & \# positive & $\%$ \\
\hline Pigs & 353 & 88 & 25.0 \\
Dogs & 192 & 36 & 19.0 \\
Rodents & 60 & 9 & 15.0 \\
Bovines & 375 & 21 & 5.6 \\
Opossums & 80 & 4 & 5.0 \\
\hline
\end{tabular}

\begin{tabular}{|c|c|c|c|c|c|}
\hline Serovar & $\begin{array}{c}\text { Bovines } \\
\%\end{array}$ & $\begin{array}{l}\text { Pigs } \\
\%\end{array}$ & $\begin{array}{c}\text { Dogs } \\
\%\end{array}$ & $\begin{array}{c}\text { Rodents } \\
\%\end{array}$ & $\begin{array}{c}\text { Opossums } \\
\%\end{array}$ \\
\hline Pomona & 4.7 & 3 & 22 & 0 & 75 \\
\hline Canicola & 0 & 0 & 14 & 0 & 0 \\
\hline Hardjo & 43.0 & 4 & 0 & 0 & 0 \\
\hline Panama & 0 & 10 & 3 & 0 & 0 \\
\hline grippotyphosa & 9.5 & 6 & 55.5 & 0 & 0 \\
\hline Wolffi & 9.5 & 8 & 0 & 14.2 & 25 \\
\hline icterohaemorrhagiae & 0 & 12 & 0 & 71.4 & 0 \\
\hline Bratislava & 4.7 & 51 & 0 & 14.2 & 0 \\
\hline Pyrogenes & 0 & 1 & 5.5 & 0 & 0 \\
\hline Tarassovi & 28.6 & 5 & 0 & 0 & 0 \\
\hline
\end{tabular}

\section{DISCUSSION}

When comparing the last reported seroprevalence for the human population in Yucatán in $1984(14.1 \%)^{24}$, with that of the present study $(14.2 \%)$, it is clear that this has changed little over the past 16 years. Leptospira continues to circulate at the same level, which is greater than in other states in México².

In this region, infection occurs at early ages, which is facilitated by patterns of work and recreation in the young and adult population ${ }^{10}$. The relatively high seropositive frequence in the elderly population can be partially explained by the long-term persistence of IgG antibodies ${ }^{14}$ though it may also be due to recent infections. The predominance of infection in men coincides with results reported for other regions of México and in other countries ${ }^{2,9}$.

Of the various serovars detected in the present, the hardjo, panama and wolffi serovars were not identified in the last leptospirosis study in Yucatán ${ }^{24}$. This introduction of new serovars may be due to the introduction of animals from other regions of México and other countries where these serovars persist. It may also result from natural disasters (e.g. hurricanes, forest fires and floods) which cause the migration of wild animals into new areas, thus creating a new epizootiological environment for transmission of new Leptospira serovars. Worth noting 


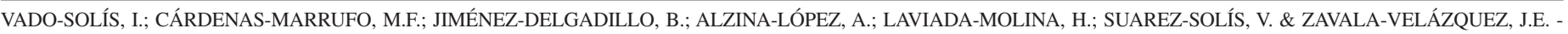
Clinical-epidemiological study of leptospirosis in humans and reservoirs in Yucatán, México. Rev. Inst. Med. trop. S. Paulo, 44(6):335-340, 2002.

is that even though the tarassovi and hardjo serovars are the most common in bovine leptospirosis, they were the two least serologically identified serovars in the human cases.

Of the studied transmission factors, the seropositive subjects interviewed for this study most commonly reported having rodents in their house or in their surroundings, and being exposed to natural water deposits (aguadas and cenotes). This suggests that the two most common ways of transmission in Yucatán are natural waters, that have been contaminated by wild and/or domestic animal urine, and contact with rodents.

On this matter clinical cases, it has been shown that IgM antibodies appear first in the early stages of infection and/or illness. However, high IgM antibody titers do not persist as long as IgG antibody titers. It is for this reason that the presence of $\operatorname{IgM}$ antibodies is considered as a marker of illness when it is associated to clinical signs and symptoms presented by the patient.

It is quite possible that the 61 recorded cases over the three years of this study do not represent all leptospirosis cases in the population during this time period. This is probable because clinically diagnosing leptospirosis can be quite difficult. In Yucatán, as in other tropical regions, its symptoms are easily confused with those of other endemic febrile etiologies from the region ${ }^{8,11,20}$, in particular with those of classic dengue in Yucatán ${ }^{26}$.

Though leptospirosis occurs in all people of all ages, it was found to be more frequent among youths and young adults. As has been reported for other regions, this is likely related to professional and recreational activities $^{7,12}$. No significant differences were found between men and women, with both sexes being equally likely to contract this disease ${ }^{15}$. The largest number of cases in this study were identified from rural areas. Here, the predominant cultural characteristics of the region, such as the close coexistence of domestic animals and people, and domestic hygiene conditions that attract peridomestic species (e.g. rodents and opossums), play an important role in creating a propitious environment for transmission of leptospirosis.

The results reported in the present study confirm the predominance of the panama serovar in confirmed anicteric and icteric cases of leptospirosis, as reported for other regions ${ }^{3,4,15}$.

Comparable to other tropical regions, the occurrence of leptospirosis demonstrates a marked seasonal variance, with the greatest number of cases recorded during the season of highest rainfall and temperature, that is, during optimum survival conditions for leptospiras ${ }^{8,9,11}$.

In comparing serovar frequency between humans and reservoirs, probable transmission routes can be drawn. Given the results, the panama serovar transmits to humans most frequently via pigs and dogs; the pomona via opossums and dogs; the icterohaemorrhagiae via rodents and pigs; the grippotyphosa via dogs and cows and the tarassovi and hardjo via cows.

As demonstrated by these results, leptospirosis is still an important pathological entity, both clinically and epidemiologically, in the State of Yucatán, México.

\section{RESUMEN}

\section{Estudio clínico-epidemiológico de leptospirosis en humanos y reservorios en Yucatán, México}

Un estudio clínico-epidemiológico de leptospirosis fue realizado en humanos y reservorios en el estado de Yucatán, México. Se entrevistaron y analizaron mediante serología 400 personas en población abierta, 439 pacientes sospechosos y 1060 reservorios (bovinos, cerdos, perros, roedores y zarigüeyas). En humanos para la detección de anticuerpos se utilizó IgM Dipstick Leptospira ${ }^{\mathrm{TM}}$ y la prueba de aglutinación microscópica (MAT) para detectar serovar. La incidencia en humanos fue de 2.2/100,000, 0.7/100,000 y 0.9/100,000 habitantes para los años 1998,1999 y 2000 respectivamente y la seroprevalencia de $14.2 \%$. La frecuencia más alta de seropositivos se encontró en mayores de 56 años, predominando el sexo masculino sobre el femenino. Predominó en población abierta el serovar tarassovi siguiendo en importancia hardjo, pomona y panamá. Los casos fueron más frecuentes en el área rural y el curso anictérico predominó sobre el ictérico. Panamá, icterohaemorrhagiae y pomona predominaron en ambos cursos de la enfermedad. Los perros cerdos y roedores tuvieron mayor positividad. El contacto con roedores y depósitos naturales de agua fue significativo ( $\mathrm{p} \leq 0.05$ ). El 74.3\% de los casos se presentaron en época de lluvia.

En conclusión la leptospirosis en Yucatán, México, sigue siendo una entidad patológica de importancia tanto clínica como epidemiológica.

\section{ACKNOWLEDGMENTS}

This research was supported by the Mexican National Council of Science and Technology (Consejo Nacional de Ciencia y Tecnología CONACyT) grant 27858-M, and by the Faculty of Medicine, Universidad Autónoma de Yucatán. Our most sincere thanks to Hugo Ruíz-Piña, M.Sc. for providing opossum serum for this project, and to the Epidemiological Monitoring System, Coordinated Health Services of the State of Yucatán (Sistema de Vigilancia Epidemiologica, Servicios Coordinados de Salud del Estado de Yucatán).

\section{REFERENCES}

1. CABALlERO, A.; ROMERO, J.; MÉNDEZ, E. \& TORRES, A.M. - Estudio serológico para la detección de anticuerpos contra leptospiras en ganado bovino lechero en los municipios de Coacalco, Teoloyucan, Zumpango, Melchor Ocampo y Cuautitlán en el Estado de México. Rev. lat.-amer. Microbiol., 31: 191-198, 1989.

2. COLÍN-ORTÍZ, J.R.; CABALLERO-SERVÍN, A.; ALARCÓN-VITAL, J.A.; PÉREZSERNA, J.C. et al. - Estudios sobre leptospirosis en México (1965-1995). Higiene, 5: 142-150, 1997.

3. DE VASCONCELOS, L.M.; RAMOS-VIEIRA, M.; OSORIO-CISALPINO, E. \& COTAKOURY, M. - Pesquisa de aglutininas anti Leptospira em trabalhadores da cidade de Londrina-Paraná, Brasil. Rev. lat.-amer Microbiol., 35: 153-157, 1993.

4. EVERARD, C.O.R.; CAWICH, F.; GAMBLE, P.G. \& EVERARD, J.D. - Prevalence of leptospirosis in Belize. Trans. roy. Soc. trop. Med. Hyg., 82: 495-499, 1998.

5. FAINE, S. - A brief overview of the disease, leptospirosis. In: FAINE, S. Leptospira and Leptospirosis. Boca Raton, CRC Press, 1994.

6. FARR, R.W. - Leptospirosis. Clin. infect. Dis., 21; 1-8, 1995.

7. JACKSON, L.A.; KAUFMANN, A.F.; ADAMS, W.G. et al. - Outbreak of leptospirosis associated with swimming. Pediat. infect. Dis. J., 12: 48-54, 1993. 
VADO-SOLÍS, I.; CÁRDENAS-MARRUFO, M.F.; JIMÉNEZ-DELGADILLO, B.; ALZINA-LÓPEZ, A.; LAVIADA-MOLINA, H.; SUAREZ-SOLÍS, V. \& ZAVALA-VELÁZQUEZ, J.E. Clinical-epidemiological study of leptospirosis in humans and reservoirs in Yucatán, México. Rev. Inst. Med. trop. S. Paulo, 44(6):335-340, 2002.

8. KO, A.; GALVÃO, M.; RIBEIRO, C.; JOHNSON Jr., W.D. \& RILEY, L. - Urban epidemic of severe leptospirosis in Brasil. Lancet, 354: 820-825, 1999.

9. MARTINEZ-SANCHEZ, R.; CRUZ DE LA PAZ, R. \& LOPEZ-ACOSTA, C. - Algunas consideraciones sobre el comportamiento de la leptospirosis humana en Cuba. Rev. cuba. Med. trop., 45: 32-41, 1993.

10. MYERS, D.M. - Manual de métodos, para el diagnóstico de la leptospirosis. Buenos Aires, Centro Panamericano de Zoonosis, 1985. (Pan American Zoonoses Center, No. 30).

11. PEROLAT, P. \& REEVE, P.A. - First evidence of leptospirosis in Vanuatu. Trans. roy. Soc. trop. Med. Hyg., 86: 557-559, 1992.

12. SAKATA, E.E.; YASUDA, P.H.; ROMERO, E.C.; SILVA, M.V. \& LOMAR, A.V. Serovares de Leptospira interrogans isolados de casos de leptospirose humana em Sao Paulo, Brasil. Rev. Inst. Med. trop. S. Paulo, 34: 217-221, 1992.

13. TURNER, L.H. - Leptospirosis II. Serology. Trans. roy. Soc. trop. Med. Hyg., 62: 880$899,1968$.

14. TURNER, L.H. - Leptospirosis. Brit. med. J., 1: 537-540, 1973.

15. VAN-CAO, T.B.; THUY-NGUYEN, T.T.; SAN-NGO, H. et al. - Human leptospirosis in the Mekong delta, Viet Nam. Trans. roy. Soc. trop. Med. Hyg., 92: 625-628, 1998.

16. VARELA, G.; VÁZQUEZ, A. \& MANCERA, L. - Investigación de aglutininas para Leptospira icterohaemorrhagiae, L. pomona y L. canicola en sueros humanos y de animales, de diversos Estados de la República Mexicana. Rev. Inst. Salubr. Enferm. trop. (Méx.), 18: 31-35, 1958.

17. VARelA, G. \& ZAVALA, J. - Estudio de leptospirosis en Yucatán. Rev. méx. Med., 42: 485-486, 1962.

18. VARELA, G. \& ZAVALA, J. - Estudios serológicos de Leptospirosis en la República Mexicana. Rev. Inst. Salubr. Enferm. trop. (Méx.), 21: 49-52, 1961.
19. VARGAS-PUERTO, F.J.; VADO-SOLIS, I.; CARDENAS-MARRUFO, M.F. \& ZAVALA-VELAZQUEZ, J. - Estudio seroepidemiologico de la leptospirosis en el estado de Yucatán. In: CONGRESO NACIONAL DE LA SOCIEDAD MEXICANA DE MEDICINA TROPICAL, 1., Cholula Puebla, Universidad de las Americas Puebla, 1999. p 16.

20. ZAKI, S.R. \& SHIEH, W.J. - Leptospirosis associated with outbreak of acute febrile illness and pulmonary haemorrhage, Nicaragua, 1995. The Epidemic Working Group at Ministry of Health in Nicaragua. Lancet, 347: 535-536, 1996.

21. ZAVALA-VELAZQUEZ, J.; BOLIO-CICERO, A. \& SUAREZ-HOIL, G. - Leptospirosis en Yucatán. Informe de un caso clínico. Patología, 14: 131-135, 1976.

22. ZAVALA-VELAZQUEZ, J.; CABALLERO-GUERRERO, C. \& SÁNCHEZ-VAZQUEZ, I. - Leptospirosis en el estado de Chiapas, México. Salud públ. Méx., 18: 989-998, 1976.

23. ZAVALA-VELAZQUEZ, J.; HERRERA-HOYOS, J. \& LAVIADA-ARRIGUNAGA F. - Leptospirosis humana en el estado de Yucatán. Reporte de dos casos. Rev. Invest. clin., 29: 161-164, 1977.

24. ZAVALA-VELAZQUEZ, J.; PINZÓN-CANTARELL, J.; FLORES-CASTILLO, M. \& DAMIÁN-CENTENO, A.G. - La leptospirosis en Yucatán. Estudio serológico en humanos y animales. Salud públ. Méx., 26: 254-259, 1984.

25. ZAVALA-VELAZQUEZ, J.; SOSA-LEAL, J.; BARRERA-PEREZ, M.A.; BOLIOCICERO, A. \& LAVIADA-ARRIGUNAGA, F.A. - Leptospirosis humana en el Estado de Yucatán. Presentación de dos nuevos casos y revisión clínica. Rev. Invest. clin., 37: 353-357, 1985.

26. ZAVALA-VELAZQUEZ, J.; VADO-SOLIS, I.; RODRÍGUEZ-FELIX, M. et al. Leptospirosis anictérica en un brote epidémico de dengue en la Península de Yucatán. Rev. Biomed., 9: 78-83, 1998.

Received: 10 January 2002

Accepted: 16 September 2002 